\title{
ANALISIS SISTEM REKRUTMEN DAN PELATIHAN DALAM MENINGKATKAN KINERJA KARYAWAN
}

\author{
Siyaha $^{\mathrm{a}}$ \\ Mansurb \\ Ridan Muhtadic \\ a,b,c Program Studi Ekonomi Syariah, STAI Miftahul Ulum, Pamekasan. \\ Email: zieyahelzai21@gmail.com; elcmansur@gmail.com; ridanmuhtadi@gmail.com
}

\begin{abstract}
Introduction: Sharia financial institutions, especially SPM Pamekasan Sharia Banks, in carrying out each of their operational activietis must depend on human resources (HR) as managers in every company activity. Therefore, SPM Pamekasan Sharia Bank must place human resources (employees) according to their field capabilities. The research here aims to be able to find out how the recruitment and training system is carried out in the SPM Pamekasan Sharia Bank and how the performance of employees using both systems.

Methods: The research method used by researchers, namely using descriptive qualitative methods, using data collection techniques in the form of observation, interviews, and documentation.

Results: The results of this study the recruitment system implemented by the SPM Pamekasan Sharia Bank uses two systems, namely internal and external recruitment and both recruitment systems are said to be quite good. For the training system implemented by the SPM Pamekasan Sharia Bank, namely an external and internal training system. Of the two recruitment and training systems carried out by Bank Syariah SPM Pamekasan have a positive effect on employee performance. This can be seen from the increase in employee performance appraisal of the SPM Pamekasan Syariah Bank which increased in 2019 compared to 2018.
\end{abstract}

Keywords: Recruitment System, Training, Employee Performance.

\section{PENDAHULUAN}

Peran sumber daya manusia pada era globalisasi saat ini dirasa sangatlah perlu terhadap sebuah pembangunan ekonomi apalagi bagi negara-negara yang berkembang. Karena pembangunan bangsa Indonesia disini Pastinya sangat tergantung pada seberapa besar kualitas Sumber Daya Manusia (SDM) yang sudah tentu sehat akan mental dan sehat fisik juga memiliki sebuah keterampilan dan keahlian dalam bekerja, sehingga nantinya mampu memiliki sebuah pekerjaan dan penghasilan yang layak, dimana nantinya akan dapat memenuhi kebutuhan hidup, ${ }^{1}$ Pendidikan, maupun kesehatan

\footnotetext{
${ }^{1}$ Muzakki, M., Eliyana, A., \& Muhtadi, R. Is employee performance affected by organizational cuoture, work motivation and organizational citizenship behavior (OCB)?: An empirical investigation. IJIEEB International
} 
keluarganya. Adapun peningkatan Sumber Daya Manusia (SDM) disini pastinya menjadi faktor yang utama. Dalam mewujudkan bangsa yang besar, sehingga bangsa Indonesia disini perlu untuk memiliki Sumber Daya Manusia (SDM) yang pastinya berkualitas, serta dapat berdaya saing yang kompetitif. ${ }^{2}$

Aktifitas utama Manajemen Sumber Daya Manusia (MSDM) disini yaitu pengadaan terhadap SDM. Dimana aktifitas tersebut berupa sebuah penyusunan program penarikan, penempatan kerja serta seleksi. Dari seluruh rangkaian dalam kegiatan tersebut pastinya tidak perlu di ragukan lagi bahwa proses rekrutmen dan pelatihan pada karyawan merupakan suatu hal yang penting. Adapun rekrutmen disini berkaitan dengan suatu pencarian dan penarikan jumlah karyawan yang memiliki potensi dan akan diseleksi serta sudah memenuhi kriteria yang diinginkan organisasi. ${ }^{3}$

Rekrutmen itu sendiri merupakan sebuah proses penarikan, mengadakan, dan mencari serta menemukan atas sekelompok kandidat yang mengajukan lamaran dimana nantinya dapat mengisi posisi yang kosong dalam sebuah organisasi ataupun perusahaan. ${ }^{4}$ Adapun tujuan dari sistem rekrutmen itu sendiri yaitu untuk memenuhi sebuah kebutuhan suatu perusahaan maupun organisasi mengenai hal sumber daya manusia yang terdapat pada perusahaan tersebut sehingga nantinya mendapatkan sumber daya manusia yang benar-benar berkualitas. Setelah selesai dilakukannya proses rekrutmen, maka untuk bisa mendapatkan karyawan yang disiplin, berprestasi, dan amanah maka diperlukan sistem pelatihan pada karyawan. Pelatihan itu sendiri merupakan suatu kegiatan yang mana sudah dirancang dalam hal mengembangkan Sumber Daya Manusia dengan melalui sebuah rangkaian kegiatan dalam identifikasi, pengkajian dengan proses belajar yang memang sudah terencana. ${ }^{5}$ Adapun tujuan dari pelatihan itu sendiri yaitu untuk dapat mengembangkan dalam hal pengetahuan, keterampilan serta sikap baru yang sudah sesuai dengan kebutuhan organisasi ataupun perusahaan. ${ }^{6}$

Bank Syariah SPM Pamekasan merupakan bagian lembaga keuangan mikro syariah. Dikarenakan lembaga keuangan syariah memiliki 2 jenis cakupan yaitu bergerak di mikro dan makro. ${ }^{7}$ Setiap lembaga keuangan syariah yang bergerak dalam

Journal of Integrated Education, Engineering and Business eISSN 2615-1596 pISSN 2615-2312, 2(1), 2019. 3642.

${ }^{2}$ Denok Sunarsi, "Pengaruh Rekrutmen, Seleksi dan Pelatihan Terhadap Produktivitas Kerja Karyawan", Jurnal Pemasaran, Sumber Daya Manusia dan Keuangan, 6 (2018), 1.

${ }^{3}$ Wiwin Purwati, "Implementasi Nilai-Nilai Islam Dalam Proses Rekrutmen dan Pengembangan Karyawan Di BMT Muamalat Limpung", (Skripsi, UIN Walisongo, Semarang, 2015), 3.

${ }^{4}$ Prof. Dr. H. Edy Sutrisno, M.Si, Manajemen Sumber Daya Manusia (Jakarta: Kencana Prenadamedia Group, 2009), 6. ${ }_{5}^{5}$ Lubis, M. Z. M. POLA REKRUTMEN DAN SELEKSI KARYAWAN PADA BMT. FreakonomicS: Journal of Islamic Economics and Finance, 1(1), 2020. 23-33..

${ }^{6}$ Intan Prawesti, "Analisis Sistem Rekrutmen, Penempatan, dan Pelatihan Dalam Meningkatkan Kinerja Karyawan BMT Permata Jatim”, (Skripsi, UIN Sunan Ampel, Surabaya, 2018), 4.

${ }^{7}$ Ervicaninda Herry dkk., "Total Quality Management Development and Sharia Governance Efforts in Sharia Micro Financial Institutions to Improve Market Share," IJIEEB : International Journal of Integrated Education, Engineering and Business 2, no. 1 (2019): 27-35, https://doi.org/10.29138/ijieeb.v2i1.809. 
menghimpun dana serta menyalurkan dana komersial dari dan kepada masyarakat yang bersifat mencari keuntungan sesuai dengan prinsip-prinsip syariah sehingga nantinya dana tersebut menjadi dana yang produktif. ${ }^{8}$ Bank Syariah SPM Pamekasan di dalam aktifitasnya pasti memerlukan Sumber Daya Manusia yang disiplin, aktif, cerdas, serta loyal. Untuk itu, Bank Syariah SPM Pamekasan menerapkan berbagai aturan dan melaksanakan sistem rekrutmen dan pelatihan bagi karyawan yang berada di dalamnya. Hal yang ditekankan oleh perusahaan hanya ingin mencari karyawan yang memang berniat untuk bekerja dengan sungguh-sungguh, disiplin, dan cerdas. Sehingga nantinya sesuai dengan operasional Bank Syariah SPM Pamekasan dalam memaksimalkan kinerja para karyawan serta dapat menunjang keberhasilan Bank Syariah SPM Pamekasan dalam mengelola usahanya.

Bank Syariah SPM Pamekasan dalam hal menerapkan sistem rekrutmen dan pelatihan disini dilakukan untuk meningkatkan kinerja karyawannya. Adapun rekrutmen yang dilakukan di dalam Bank Syariah SPM Pamekasan berdasarkan kebutuhan akan tenaga kerja dan juga kebijakan Bank Syariah SPM dalam melakukan perekrutan karyawan dikarenakan banyaknya tambahan nasabah serta juga apabila Bank Syariah SPM membuka cabang baru. Bank Syariah SPM Pamekasan disini melakukan proses rekrutmen dengan dua cara yaitu dengan merekrut anak magang maupun karyawan tetap dan juga dapat merekrut karyawan dari luar yang mengajukan surat lamaran dengan memenuhi persyaratan yang memang telah ditetapkan serta sudah dijalankan oleh pihak Bank Syariah SPM Pamekasan. Adapun salah satu syarat yang ditetapkan pihak Bank Syariah SPM dari dua cara tersebut yaitu tidak harus lulusan sarjana ekonomi Syariah. Sedangkan untuk pelatihan yang dilakukan oleh Bank Syariah SPM Pamekasan disini bermacam-macam guna untuk meningkatkan kinerja para karyawan. Pelatihan yang dilakukan disini bersifat formal serta non-formal, dan juga pelatihan yang dilakukan berasal dari lingkungan internal serta eksternal perusahaan..$^{9}$

Intan prawesti dalam peneletiannya disini menyatakan bahwa hasil yang diperoleh dalam pelaksanaan sistem rekrutmen, penempatan dan pelatihan dalam meningkatkan kinerja karyawan BMT Permata Jatim dapat dikatakan cukup baik dengan menggunakan sistem rekrutmen inernal serta eksternal. Dan mengenai penempatan karyawan sudah cukup baik juga dalam penerapan yang dilakukan dengan benar. Adapun mengenai sistem pelatihan yang digunakannya yaitu pelatihan tingkat mikro serta makro. Adapun dari keseluruhan sistem rekrutmen, penempatan serta pelatihan dalam BMT

\footnotetext{
${ }^{8}$ Muslikhin, M., Kinanti, R. A., Muhtadi, R., \& Fudholi, M. PEMERIKSAAN EMPIRIS PADA PENGARUH KINERJA SOSIAL TERHADAP PROFITABILITAS DI BANK SYARIAH. Ulumuna: Jurnal Studi Keislaman, 6(1), 2020. $72-$ 84. Lihat juga, Rosyadah, P. C., Arifin, N. R., Muhtadi, R., \& Safik, M. (2020). Factors That Affect Savings In Islamic Banking. AL-ARBAH: Journal of Islamic Finance and Banking, 2(1), 33-46.

9 Iqbal, Wawancara, 13-Oktober-2020.
} 
Permata Jatim berdampak baik pada kinerja para karyawan yang mana dapat dilihat dari peningkatan penilaian kinerja karyawan dari tahun 2016 sampai pada tahun 2018.10

Semakin banyak perkembangan lembaga keuangan syariah maka persainganpersaingan antara perusahaan disini juga tidak dapat dihindari. Oleh sebab itu sumber daya manusia yang berada dalam sebuah perusahaan pastinya harus mampu dalam mengembangkan diri karena dalam setiap perusahaan yang ada pastinya akan menginginkan untuk mendapatkan sumber daya manusia yang mempunyai kualitas serta mampu diunggulkan dalam mencapai suatu misi serta visi perusahaan agar dapat bersaing serta mampu menjadi perusahaan yang unggul.11 Adapun permasalahan yang ada dalam lembaga keuangan syariah disini yaitu bagaimana kualitas serta kuantitas pada sumber daya manusia yang dimiliki perusahaan tidak dapat memenuhi akan kualifikasi yang ditetapkan oleh lembaga keuangan syariah. Dimana untuk sumber daya manusia disini pastinya di haruskan untuk mampu dalam pemahaman akan ilmu ekonomi konvensional dan syariah, tetapi kenyataannya sumber daya manusia pada lembaga keuangan Bank Syariah SPM Pamekasan beberapa karyawannya berasal dari jurusan ekonomi konvensional dan beberapa karyawannya juga untuk awal pengalaman bekerja di lembaga bank konvensional. Sedangkan untuk pengetahuan akan ekonomi syariah masih minim dalam segi pemahaman terhadap produk ataupun akad-akad yang ada di Bank Syariah SPM Pamekasan, Oleh karena itu maka lembaga keuangan Bank Syariah SPM Pamekasan memiliki tantangan terbesar bagaimana Bank Syariah SPM disini mampu menjadikan sumber daya manusia ataupun karyawan yang ada dalam perusahaan mempuni dalam pemahaman produk-produk maupun akad yang ada di Bank Syariah SPM yang sudah sesuai dengan prinsip syariah. Karena nantinya keuntungan dari perusahaan itu sendiri akan meningkat ketika manajemen dalam perusahaan khususnya Sumber Daya Manusia (SDM) yang terdapat dalam perusahaan dapat diatur dengan baik menggunakan prinsip-prinsip Syariah. ${ }^{12}$

Proses tersebut sangat penting untuk dilakukan perusahaan demi kemajuan perusahaan terutama dalam hal kinerja karyawan. Maka tujuan penulis dalam melakukan penelitian disini yaitu untuk mengetahui bagaimana sistem rekrutmen dan sistem apa saja yang dilakukan dalam pelatihan untuk dapat meningkatkan kinerja para karyawan di Bank Syariah SPM Pamekasan.

\section{LITERATURE REVIEW}

\section{Sumber Daya Manusia (SDM)}

Sumber Daya Manusia disini merupakan salah satu faktor yang dikatakan penting dalam sebuah Lembaga keuangan Syariah seperti halnya bank Syariah dimana, Bank

\footnotetext{
${ }^{10}$ Intan Prawesti, "Analisis Sistem Rekrutmen, Penempatan, dan Pelatihan Dalam Meningkatkan Kinerja Karyawan BMT Permata Jatim", hal 79.

${ }^{11}$ Intan Prawesti, "Analisis Sistem Rekrutmen, Penempatan, dan Pelatihan Dalam Meningkatkan Kinerja Karyawan BMT Permata Jatim", hal 6.

${ }^{12}$ Iqbal, Wawancara, 15-Oktober-2020.
} 
Syariah disini tidak dapat dipisahkan dari gagasan yang pastinya lebih luas, yaitu ekonomi islam..$^{13}$ Oleh sebab itu Sumber Daya Manusia haruslah mampu dikelola dengan sebaik mungkin untuk nantinya dapat meningkatkan terhadap efektifitas serta efisiensi dalam organisasi. ${ }^{14}$

Sedangkan definisi Manajemen Sumber Daya Manusia (MSDM) disini merupakan suatu aktifitas yang berupa perencanaan, penggunaan, pengembangan, pemeliharaan serta suatu pengadaan terhadap sumber daya manusia (SDM) dalam mencapai suatu tujuan baik secara individu maupun organisasi. ${ }^{15}$ Adapun tujuan utama dari MSDM disini yaitu dapat memperbaiki ataupun meningkatkan produktivitas, dan dapat memperbaiki terhadap sebuah kualitas dalam kehidupan bekerja, serta untuk dapat meyakinkan pada organisasi maupun perusahaan bahwa telah mampu dalam memenuhi aspek-aspek legal. ${ }^{16}$ Hal tersebut dapat dipahami bahwa semua kegiatan atau aktivitas organisasi dalam mencapai suatu tujuan tergantung pada manusia yang mengelola organisasi atau perusahaan tersebut. Oleh sebab itu, MSDM memang harus benar-benar dikelola dengan baik sehingga dapat berdaya guna serta berhasil dalam mencapai setiap tujuan dari perusahaan.

\section{Rekrutmen}

Rekrutmen merupakan sebuah proses dimana untuk mencari serta menemukan ataupun untuk menarik seseorang yang sedang melamar pekerjaan sehingga nantinya dapat dipekerjakan di dalam sebuah organisasi maupun perusahaan. ${ }^{17}$

\section{Sumber-Sumber Rekrutmen}

Dalam perekrutan karyawan disuatu perusahaan dapat dilakukan dengan dua sumber yaitu sumber rekrutmen internal dan sumber rekrutmen eksternal.

1. Sumber Rekrutmen Internal

Untuk mendapat karyawan yang baik dan handal dalam mengisi posisi lowong itu bisa dari internal perusahaan. Kekosongan posisi dapat diberikan terhadap karyawan yang memang dianggap cocok sehingga hal itu dapat memotivasi para karyawan tersebut serta karyawan lainnya untuk dapat bekerja lebih baik lagi. Dalam pengisian posisi secara internal disini dapat dilakukan dengan promosi, rotasi, dan demosi. Dimana promosi disini merupakan kenaikan jabatan, rotasi itu sendiri merupakan perpindahan suatu jabatan pada level yang sama, sedangkan demosi merupakan penurunan sebuah jabatan. ${ }^{18}$

2. Sumber Rekrutmen Eksternal

\footnotetext{
13 Mansur, "Bank Syariah Antara Labelisasi dan Pemberdayaan Ekonomi Masyarakat", Jurnal, Studi Keislaman, 4 (2018), 1.

14 Nika Rizki Amalia, "Analisis Proses Rekrutmen dan Seleksi Karyawan Pada BMT Alfa Dinar Kantor Pusat Karanganyar”, (Skripsi, IAIN Salatiga, 2017), 17.

15 Prof. Dr. H. Edy Sutrisno, M.Si, Manajemen Sumber Daya Manusia, hal, 6.

16 Prof. Dr. H. Edy Sutrisno, M.Si, Manajemen Sumber Daya Manusia, hal, 8.

${ }^{17}$ Prof. Dr. H. Edy Sutrisno, M.Si, Manajemen Sumber Daya Manusia, hal, 45.

18 Dwi Wahyu Marina Setyawati, “Analisis Proses Rekrutmen Karyawan Pada KSPS BMT Surya Melati Gubug Grobogan”, (Skripsi, IAIN Salatiga, 2019), 30.
} 
Rekrutmen eksternal disini merupakan proses perekruten dalam suatu perusahaan yang berasal dari luar perusahaan. Apabila tidak terdapat karyawan didalam internal perusahaan yang memang cocok untuk dapat mengisi sebuah posisi yang dibutuhkan maka suatu perusahaan dapat melakukan perekrutan karyawan yang berasal dari luar perusahaan. Dan juga perusahaan dapat melakukan rekrutmen eksternal apabila perusahaan disini melakukan perluasan bisnis sehingga akibatnya membutuhkan tenaga kerja yang banyak. Lingkungan eksternal perusahaan disini berupa perusahaan penyedia tenaga kerja, kantor penempatan tenaga kerja, serikat pekerja, lembaga Pendidikan, masyarkat umum, serta lembaga pemerintah. ${ }^{19}$

\section{Pelatihan}

Pelatihan merupakan sebuah proses dalam memberikan suatu bantuan bagi para karyawan untuk dapat manguasai sebuah keterampilan yang khusus ataupun untuk dapat membantu dalam memperbaik setiap kekurangan yang dimiliki dalam melaksanakan sebuah pekerjaan. ${ }^{20}$ Adapun pelatihan disini bertujuan untuk para karyawan dapat meningkatkan akan kemampuannya dalam melaksanakan pekerjaannya, karena dengan persaingan yang semakin meningkat serta perkembangnya zaman yang semakin maju, maka pastinya para karyawan dituntut untuk terus meningkatkan akan kemampuannya sehingga nantinya tidak ketinggalan dari banyaknya pesaing. Karena jika semakin meningkat performa para karyawan maka dapat dipastikan akan berdampak baik pada perusahaan maupun organisasi. ${ }^{21}$

\section{Tujuan Pelatihan}

Selain bertujuan dalam meningkatkan produktifitas serta efisiensi karyawan pelatihan disini juga dapat menambah dalam keterampilan karyawan serta dapat mengasah suatu keahlian yang memang sudah dimiliki sehingga nantinya dapat menjadi suatu langkah yang penting yang diambil oleh perusahaan untuk bisa bertahan dalam kompetisi. Berikut beberapa tujuan pelatihan:

1. Meningkatkan Produktifitas

Salah satunya dengan cara memanfaatkan dengan baik teknologi yang ada karena dalam perkembangan teknologi saat ini sangatlah cepat. sehingga membantu pelatihan karyawan untuk menguasai teknologi juga dapat berkembang cepat. Selain itu para karyawan juga dapat mengembangkan suatu cara ataupun metode sehingga nantinya akan mampu dalam hal menyelesaikan pekerjaannya dengan efektif serta efisien.

2. Memperbaiki Kualitas

\footnotetext{
${ }^{19}$ Dwi Wahyu Marina Setyawati, "Analisis Proses Rekrutmen Karyawan Pada KSPS BMT Surya Melati Gubug Grobogan”, hal, 31.

${ }^{20}$ Intan Prawesti, "Analisis Sistem Rekrutmen, Penempatan, dan Pelatihan Dalam Meningkatkan Kinerja Karyawan BMT Permata Jatim", hal, 46.

${ }^{21}$ Erwin Nurhuda, Djamhur Hamid, M. Faisal Riza, "Analisis Pelaksanaan Program Rekrutmen, Seleksi, Penempatan Kerja, dan Pelatihan Karyawan", hal, 4.
} 
Para karyawan juga nantinya akan mampu memberikan suatu layanan ataupun dapat menghasilkan suatu produk yang lebih baik sehingga hal tersebut akan dapat mempertahankan para pelanggan atau klien.

3. Meningkatkan Potensi Karyawan

Hal ini dapat membantu para karyawan untuk dapat percaya diri sehingga nantinya para karyawan akan lebih betah unuk bekerja dalam perusahaan. karena para karyawan akan menganggap perusahaan peduli akan kebutuhan para karyawan.

\section{Strategi Program Pelatihan}

1. Pelatihan Tingkat Mikro

Dalam pelatihan ini dilaksanakan oleh perusahaan itu sendiri, dimana sesuai dengan dengan kebutuhan dalam hal meningkatkan suatu kemampuan para karyawan dalam melaksanakan pekerjaannya sehingga menjadi maksimal. ${ }^{22}$

2. Pelatihan Tingkat Makro

Dalam pelatihan ini dilaksanakan oleh dua perusahaan atau lebih yang mana sama-sama membutuhkan dalam meningkatkan suatu kemampuan para karyawan masing-masing. ${ }^{23}$

\section{Kinerja Karyawan}

Kinerja karyawan merupakan hal yang mempunyai suatu sifat yang individu sebab setiap karyawan pastinya mempunyai suatu tingkat kualifikasi yang berbeda-beda serta kinerja yang berbeda pula dalam setiap kaitan dengan tugasnya. Penilaian terhadap kinerja karyawan pada lembaga keuangan syariah disini sangatlah penting untuk dilakukan untuk dapat mengetahui tingkat efektifitas serta efisiensi perusahaan dalam mencapai sebuah tujuan perusahaan tersebut. ${ }^{24}$

1. Faktor Yang Harus di Perhatikan Dalam Penilaian Kinerja Karyawan

a. Kualitas Kerja, hal ini dapat dilihat dari seberapa banyak pekerjaan atau mampu untuk dapat dikerjakan dalam waktu yang efektif serta efisien.

b. Kualitas Kerja, merupakan sebuah indikator yang pastinya penting dalam kinerja para karyawan anda sendiri.

c. Pemahaman Tentang Pekerjaan, hal ini merupakan suatu hal penting yang pastinya dipunyai oleh karyawan terkait dengan kinerjanya dalam suatu pekerjaan.

d. Membuat Perencanaan Kegiatan, hal ini dapat menjadi sebuah rencana yang dapat dilakukan dalam hal mengevaluasi kinerja para karyawan.

\footnotetext{
${ }^{22}$ Intan Prawesti, "Analisis Sistem Rekrutmen, Penempatan, dan Pelatihan Dalam Meningkatkan Kinerja Karyawan BMT Permata Jatim”, hal, 47.

${ }^{23}$ Intan Prawesti, "Analisis Sistem Rekrutmen, Penempatan, dan Pelatihan Dalam Meningkatkan Kinerja Karyawan BMT Permata Jatim", hal, 47.

${ }^{24}$ Muslikhin, Risma Ayu Kinanti, Ridan Muhtadi, Moh. Fudholi, "Pemeriksaan Empiris Pada Pengaruh Kinerja Sosial Terhadap Profitabilitas Di Bank Syariah”, Jurnal, Studi Keislaman, 6 (2020), 1.
} 
2. Faktor Yang Mempengaruhi Kinerja Karyawan

a. Faktor Efisiensi dan Efektifitas, jika suatu tujuan dalam perusahaan dapat tercapai, maka hal tersebut dapat dikatakan bahwa kegiatan tersebut merupakan kegiatan yang efektif.

b. Faktor Otoritas, merupakan suatu perintah dalam suatu perusahaan untuk dapat memberitahukan apa yang bisa dan apa yang tidak bisa dalam sebuah perusahaan.

c. Faktor Disiplin, merupakan sebuah perjanjian kerja para karyawan dengan perusahaan yang bersangkutan.

d. Faktor Inisiatif, merupakan suatu pengembangan ide dalam merencanakan suatu hal yang berkaitan langsung dengan tujuan perusahaan. ${ }^{25}$

\section{METODE PENELITIAN}

Dalam penelitian ini mengenai sistem rekrutmen dan pelatihan karyawan di Bank Syariah SPM Pamekasan disini menggunakan jenis penelitian kualitatif deskriptif yaitu peneliti melakukan penelitian lapangan oleh sebab itu, peneliti disini langsung ke Bank Syariah SPM Pamekasan, dimana nantinya peneliti akan mendiskripsikan hasil yang di peroleh di lapangan baik berupa kata-kata baik secara tertulis maupun secara lisan apa yang sudah diamati dan sudah ditemukan dilapangan ataupun di Bank Syariah SPM Pamekasan.

Adapun untuk teknik pengumpulan data yang digunakan dalam penelitian disini yaitu Teknik pengumpulan data berupa observasi, wawancara, dan dokumentasi. Peneliti melakukan observasi secara langsung untuk menemukan sebuah pengamatan mengenai proses rekrutmen dan pelatihan untuk meningkatkan kinerja karyawan di Bank Syariah SPM Pamekasan yang sesuai dengan kenyataan serta fakta yang ada. Wawancara yang dilakukan oleh peneliti disini tertuju lansung kepada ibu Gita selaku menjabat sebagai pimpinan sumber daya insani, peneliti juga mewawancarai bapak Iqbal selaku menjabat sebagai kasi funding serta peneliti juga mewawancarai bapak suhari yang menjabat sebagai pimpinan di kantor SPM Kas Bandaran, dan ibu liza dan bapak sofyan selaku teller di kantor SPM Kas Bandaran dan di Kantor SPM Ummul Quro Blumbungan. Dengan mempersiapkan terlebih dahulu mengenai pertanyaan-pertanyaan akan informasi yang dibutuhkan yaitu mengenai sistem rekrutmen dan pelatihan karyawan yang diterapkan oleh kantor Bank Syariah SPM Pamekasan dalam meningkatkan akan kinerja karyawan. Tidak hanya melalui teknik observasi dan wawancara untuk mendapatkan sebuah informasi tetapi, dapat diperoleh melalui dokumentasi yaitu dengan fakta yang tersimpan dalam bentuk sebuah surat ataupun sebuah catatan harian, jurnal kegiatan dan lain-lain. ${ }^{26}$ Dimana peneliti juga mendapatkan informasi dari buku, jurnal, serta skripsi yaitu data

\footnotetext{
${ }^{25}$ https://adalah.co.id/kinerja-karyawan/diakses -pada-tanggal-27-Oktober-2020.

26 https://www.uin-malang.ac.id/r/110601/metode-pengumpulan-data-penelitian-kualitatif.html-diakses-padatanggal-27-Oktober-2020.
} 
mengenai sistem perekrutan dan pelatihan juga mengenai penilaian kinerja karyawan di Bank Syariah SPM Pamekasan dan juga syarat-syarat yang diterapkan perusahaan dalam merekrut karyawan.

Adapun untuk analisis data maka, setelah mendapatkan sebuah data dari masingmasing prosedur pengambilan data, sehingga pada tahapan selanjutnya yaitu menganalisis data-data yang sudah diperoleh tersebut sehingga nantinya akan menjadi sebuah data yang mudah untuk di cermati. Reduksi data merupakan sebuah langkah dalam merangkum beberapa data yang sudah diperoleh, memilih data yang urgen, memilih data yang diperlukan serta memfokuskan pada data yang pokok. Peneliti disini mengumpulkan data yang diperoleh mengenai sistem rekrutmen dimana sistem rekrutmen yang diterapkan di kantor Bank Syariah SPM Pamekasan yaitu rekrutmen internal dan eksternal. Sedanghkan untuk sistem pelatihannya yaitu menggunakan pelatihan secara internal dan eksternal pula, untuk penilaian kinerja karyawan yaitu terdapat beberapa kriteria yang digunakan dalam melakukan penilaian terhadap kinerja karyawan sesuai dengan ketentuan Bank Syariah SPM Pamekasan. Setelah peneliti merangkum hasil data-data yang sudah diperoleh melalui tahap reduksi data, selanjutnya peneliti akan memaparkan-nya secara sistematik. Dimana peneliti akan memaparkan secara jelas dan rinci dari hasil yang sudah diperoleh dari tahapan reduksi data mengenai sistem rekrutmen yang di terapkan di Bank Syariah SPM Pamekasan dan juga sistem pelatihan serta penilaian akan kinerja para karyawan. Melalui proses pemaran tersebut harapan peneliti dapat memberikan sebuah penjelasan secara tepat mengenai objek penelitian yang sesuai dengan ketentuan dan perundang-undangan. Serta nantinya diharap bisa mempermudah untuk menarik sebuah kesimpulan. Setelah dilakukannya tahapan reduksi data serta memaparkanya, maka tahapan selanjutnya yaitu peneliti akan memberikan kesimpulan dengan singkat dan padat. Mengenai sistem rekrutmen dan pelatihan dalam meningkatkan kinerja karyawan di Bank Syariah SPM Pamekasan.

\section{HASIL DAN PEMBAHASAN}

\section{Sistem Rekrutmen dan Pelatihan}

Sistem perekrutan serta pelatihan pada lembaga keuangan syariah Bank Syariah SPM Pamekasan dilakukan untuk kemajuan akan kinerja para karyawan yang ada didalamnya. Proses yang dilakukan dalam merekrut karyawan di Bank Syariah SPM Pamekasan dengan menggunakan dua metode yaitu internal serta eksternal. Dimana untuk metode internal sendiri yaitu merekrut karyawan dari anak magang serta dari karyawan lama, sedangkan untuk metode eksternal disini merekrut dari surat lamaran yang sudah masuk pada Bank Syariah SPM Pamekasan. Adapun untuk media yang digunakan Bank Syariah SPM Pamekasan dalam merekrut karyawan disini yaitu menggunakan media internet, koran, radio karimata, serta dari mulut kemulut. ${ }^{27}$ Rekrutmen karyawan yang dilakukan oleh Bank SPM Pamekasan disini apabila Bank

${ }^{27}$ Doni, Wawancara, 30-September-2020 
Syariah SPM membutuhkan karyawan baru karena terdapat kekosongan posisi ataupun jabatan, dan juga Bank Syariah SPM melakukan perekrutan apabila nasabah bank yang semakin banyak serta apabila Bank Syariah SPM Pamekasan membuka cabang baru sehingga membutuhkan karyawan baru untuk dapat mengisinya. ${ }^{28}$

Adapun untuk syarat-syarat yang harus diisi dalam surat lamaran pekerjaan yang terapkan di Bank SPM Pamekasan yaitu:

1. Laki-laki atau perempuan

2. Riwayat Hidup

3. Surat keterangan sehat

4. SKCK

5. Transkip Nilai Ijazah

Untuk selanjutnya setelah rekrutmen dilakukan karyawan disini juga akan mendapatkan sebuah pelatihan yang sudah diterapkan oleh Bank Syariah SPM Pamekasan. Yaitu pelatihan karyawan disini dari tingkat makro serta tingkat mikro. Dimana untuk pelatihan mikro dilaksanakan setiap bulan oleh Bank Syariah SPM Pamekasan untuk mengevaluasi kinerja para karyawan yang diikuti seluruh karyawan tetapi di pisah sesuai porsi ataupun sesuai jabatan masing-masing. Sedangkan untuk pelatihan dari tingkat makro yang dilakukan oleh Bank Syariah SPM Pamekasan bersama bank syariah lainnya yang berada di indonesia dengan mengirim beberapa karyawan sesuai dengan jabatan yang akan diberikan pelatihan. Adapun pelatihan disini bertujuan dalam meningkatkan produktivitas kinerja para karyawan. Pelatihan yang diberikan kepada para karyawan lama maupun karyawan baru. ${ }^{29}$

\section{Peningkatan Kinerja Karyawan Di Bank Syariah SPM Pamekasan}

Dengan sistem rekrutmen serta sistem pelatihan yang digunakan oleh Bank Syariah SPM Pamekasan disini mempunyai sebuah peningkatan dalam kinerja karyawan. Terdapat beberapa kriteria yang dijadikan sebagai sebuah penilaian akan kinerja para karyawan oleh Bank Syariah SPM Pamekasan diantaranya yaitu:

1. Keaktifan

2. Kedisiplinan

3. Prestasi (Pencapaian Target)

4. Kerapian

5. Loyalitas

Tabel 1.1

Kriteria Penilaian akan kinerja para karyawan Bank Syariah SPM Pamekasan

\begin{tabular}{|c|c|c|c|}
\hline No & $\begin{array}{c}\text { Kriteria } \\
\text { penilaian }\end{array}$ & $\begin{array}{c}\text { Penilaian kinerja } \\
\text { Tahun 2018 (\%) }\end{array}$ & $\begin{array}{c}\text { Penilaian Kinerja } \\
\text { Tahun 2019 (\%) }\end{array}$ \\
\hline 1 & Keaktifan & $70 \%$ & $85 \%$ \\
\hline
\end{tabular}

28 Suhari, Wawancara, 30-September-2020

${ }^{29}$ Gita, Wawancara, 14-Oktober-2020. 


\begin{tabular}{|l|c|c|c|}
\hline 2 & Kedisiplinan & $80 \%$ & $85 \%$ \\
\hline 3 & Prestasi & $70 \%$ & $80 \%$ \\
\hline 4 & Kerapian & $60 \%$ & $70 \%$ \\
\hline 5 & Loyalitas & $50 \%$ & $90 \%$ \\
\hline
\end{tabular}

Sumber: Data Diolah Tahun $2020^{30}$

Dilihat pada tabel diatas kriteria penilaian kinerja karyawan Bank Syariah SPM Pamekasan mengalami peningkatan pada tahun 2019 dari pada tahun 2018. Kriteria dari keaktifan meningkat $15 \%$ pada tahun 2019 dibandingkan pada tahun 2018 hal ini pastinya akan berdampak positif terhadap perusahaan, keaktifan disini dapat dilihat dari karyawan tersebut yang selalu mempunyai suatu inisiatif serta mempunyai ide-ide baru dalam mengembangkan perusahaan. Untuk kriteria kedisiplinan pada tahun 2019 mengalami peningkatan $5 \%$ dibandingkan tahun 2018. Sedangkan untuk kriteria prestasi juga mengalami peningkatan sebesar $10 \%$ hal ini dapat dilihat dari karyawan yang mampu mencapai target yang ditetapkan perusahaan hal ini tidak hanya akan berdampak positif bagi perusahaan tetapi juga pada karyawan yang mampu mencapai ataupun melebihi target karena natinya karyawan tersebut akan mendapatkan reward dari perusahaan. Selain itu untuk kriteria lainnya seperti kriteria kerapian pada tahun 2019 juga mengalami peningkatan sebanyak $10 \%$ dibandingkan pada tahun 2018, dan loyalitas disini juga mengalami peningkatan sebanyak 40 \% pada tahun 2019 dibandingkan tahun 2018. Hal tersebut terbukti dari kekompakan antara karyawan di Bank Syariah SPM Pamekasan.

\section{Pembahasan}

\section{Analisis Sistem Rekrutmen dan Pelatihan Di Bank SPM Pamekasan}

Sistem rekrutmen yang diterapkan di Bank Syariah SPM Pamekasan yaitu dengan menggunakan sistem rekrutmen internal serta eksternal, Untuk rekrutmen internal di Bank Syariah SPM Pamekasan diterapkan karena ada kenaikan jabatan bagi karyawan yang sudah lama tetapi dengan syarat bahwa karyawan lama berhak naik jabatan apabila kinerja dari karyawan tersebut sudah memenuhi target operasional yang sudah ditetapkan oleh Bank Syariah SPM serta mendapat penilaian kinerja yang baik dari kriteria-kriteria yang sudah disebutkan diawal. Dalam perekrutan internal disini dapat mengambil dari anak magang dan karyawan lama di Bank Syariah SPM Pamekasan Sehingga pihak bank sudah tidak khawatir dan merasa yakin untuk menempatkan karyawan ataupun menaikkan jabatannya dikarenakan karyawan tersebut sebelumnya sudah mendapat penilaian kinerja yang baik. Hal ini sangatlah berguna agar karyawan yang memiliki kemampuan serta karyawan yang memiliki kinerja yang baik dilihat dari kemampuan karyawan tersebut dalam mencapai target yang sudah ditetapkan oleh pihak bank tidak keluar dari Bank Syariah SPM Pamekasan. Sehingga pihak Bank Syariah SPM

\footnotetext{
${ }^{30}$ Iqbal, Wawancara, 21-Oktober-2020.
} 
Pamekasan disini haruslah memperhitungkan karyawan yang sudah jelas-jelas memiliki kemampuan dalam bekerja dengan cara menaikkan jabatannya.

Sedangkan untuk rekrutmen eksternal yang diterapkan oleh Bank Syariah SPM Pamekasan yaitu pihak bank akan merekrut karyawan dari surat lamaran yang sudah masuk pada Bank Syariah SPM Pamekasan. Setelah itu, pihak Bank akan memanggil pelamar untuk nantinya akan dilakukan beberapa teks yaitu teks tulis dan wawancara. Pelamar yang sudah memenuhi persyaratan maka pelamar tersebut akan diterima menjadi bagian karyawan Bank Syariah SPM Pamekasan. Untuk media yang digunakan diantaranya yaitu koran, brosur, radio karimata, internet dan dari mulut kemulut. Dimana pihak bank disini akan memberikan brosur kepada nasabah yang datang ke bank untuk melakukan penarikan maupun penyetoran tabungan. Untuk syarat-syarat yang ditetapkan oleh Bank Syariah SPM Pamekasan disini yang paling dikedepankan adalah keaktifan, dikarenakan calon karyawan yang tidak aktif maka akan berpengaruh negatif terhadap kinerja dari karyawan tersebut. ${ }^{31}$

Sedangkan untuk sistem pelatihan yang diterapakan oleh Bank Syariah SPM Pamekasan yaitu menerapkan sistem pelatihan internal dan eksternal. Dimana untuk pelatihan internal Bank Syariah SPM Pamekasan akan memberikan pelatihan kepada karyawan lama ataupun pada karyawan baru, untuk karyawan baru disini akan diberikan pelatihan khusus selama kurang lebih satu minggu untuk memberikan pelatihan mengenai pemahaman syariah dan juga memberikan pemahaman akan produk-produk dan akad-akad yang ada dalam Bank Syariah SPM Pamekasan. dikarenakan beberapa karyawan berasal dari sarjana ekonomi konvensional ataupun dikarenakan ada beberapa karyawan dimana pengalaman awal bekerja di bank konvensional, sehingga Bank Syariah SPM Pamekasan disini haruslah memberikan pelatihan yang husus bagi karyawan baru untuk nantinya dapat memahami akan produk-produk serta akad-akad secara mendalam dan juga akan lebih memahami terhadap pengetahuan syariah, karena Bank Syariah SPM Pamekasan merupakan lembaga yang sudah berbasis syariah. Maka semua karyawan yang ada didalamnya haruslah memiliki kemampuan ak+an pengetahuan syariah untuk nantinya ketika mempromosikan prduk-produk ke pada masyarakat dapat bejalan dengan baik karena karyawan tersebut sudah memahami mengenai produk-produk yang ada di Bank Syariah SPM Pamekasan. Sedangkan untuk pelatihan bagi karyawan lama disini Bank Syariah SPM Pamekasan memberikan pelatihan sesuai dengan jabatan karyawan dan dibimbing oleh masing-masing senior dalam setiap jabatan. Hal tersebut dilakukan agar perkembangan kinerja karyawan semakin baik dan memiliki kesemangatan dalam bekerja. Serta juga dilakukannya pelatihan disini untuk dijadikan sarana evaluasi kinerja karyawan agar tidak terjadi penurunan kinerja karyawan.

Sedangkan untuk pelatihan eksternal disini Bank Syariah SPM Pamekasan bekerja sama dengan Bank-Bank lain dengan mengikut sertakan karyawan Bank Syariah SPM

${ }^{31}$ Iqbal, Wawancara, 22-Oktober-2020. 
Pamekasan. Dan Bank Syariah SPM disini melakukan pelatihan eksternal ketika sedang ada study banding biasanya mengenai produk-produk baru, dimana nantinya jika ada produk baru yang diperkenalkan bank lain dapat juga diterapkan oleh Bank Syariah SPM dan sebaliknya jika terdapat produk baru yang dikeluarkan Bank Syariah SPM Pamekasan dapat juga ditiru oleh bank lain. Hal tersebut tidak menjadi masalah tetapi, akan semakin mempererat kerja sama dengan bank-bank lain. Selain pelatihan tersebut juga terdapat pelatihan eksternal lainnya seperti jika instansi ataupun bank lain mengadakan pelatihan untuk bagian marketing, umum dan akuntan, maka Bank Syariah SPM akan mengirim beberapa karyawan untuk mengikuti pelatihan tersebut sesuai dengan bagian ataupun sesuai dengan jabatan yang akan di lakukan pelatihan. Tujuan diadakan pelatihan internal ataupun eksternal disini selain untuk dapat mengetahui produk-produk baru yang diperkenalkan juga untuk perkembangan akan kinerja setiap karyawan. Karena jika terdapat kinerja karyawan yang menurun maka bank tersebut akan melakukan sebuah evaluasi ataupun memberikan pelatihan agar nantinya perkembangan kinerja karyawan semakin baik disetiap tahunnya.

\section{Sistem Rekrutmen dan Pelatihan Dalam Meningkatkan Kinerja Karyawan Bank Syariah SPM Pamekasan.}

Kinerja para karyawan dilihat dari tabel diatas mengalami peningkatan pada tahun 2019 dibandingkan tahun 2018. Hal tersebut dikarenakan sistem yang dijalankan oleh Bank Syariah SPM Pamekasan cukup baik dimana dapat dilihat dari sistem rekrutmen dan pelatihan. Untuk syarat-syarat dalam perekrutan di Bank Syariah SPM Pamekasan disini tidak harus lulusan sarjana ekonomi syariah meskipun sarjana ekonomi umum maupun lulusan bidang lainnya masih mendapat peluang untuk bekerja dalam lembaga keuangan syariah seperti di Bank Syariah SPM Pamekasan karena tidak semua jabatan yang ada dalam Bank Syariah SPM harus dari sarjana ekonomi syariah seperti untuk jabatan IT (Information Technology), driver, satpam dan lain sebagainya. Tetapi Bank Syariah SPM lebih menekankan pada hal kedisiplinan, keaktifan dan kesungguhan karyawan dalam bekerja hal tersebut nantinya akan meningkatkan kinerja para karyawan sehingga akan berdampak positif bagi Bank Syariah SPM sendiri. Hal tersebut juga dapat dilihat dari kriteria kedisiplinan dan keaktifan para karyawan yang meningkat pada tahun 2019 dibandingkan tahun 2018.

Untuk sistem pelatihan yang diterapkan di Bank Syariah SPM disini yaitu pelatihan internal dan eksternal. Pelatihan yang dilakukan oleh Bank Syariah SPM Pamekasan juga berdampak pada kinerja karyawan karena pelatihan tersebut dapat menjadi tambahan pengetahuan dan kesemangatan karyawan dalam bekerja dan juga dapat berdampak positif untuk kriteria prestasi karyawan yang mana nantinya untuk kriteria prestasi karyawan dilihat dari kemampuan karyawan dalam mencapai target yang sudah ditetapkan oleh pihak bank. Sehingga ketika karyawan tersebut sudah mencapai target maka karyawan tersebut selain mendapatkan reward ataupun bonus dari pihak bank juga 
dapat naik jabatan. Tetapi jika karyawan tidak mencapai target maka pihak bank akan memberikan punishmand ataupun hukuman berupa uang tunjangan dan fasilitas kantor akan dikurangi. Oleh sebab itu pelatihan internal ataupun eksternal yang diberikan perusahaan akan dapat meningkatkan kinerja karyawan hal ini dapat dilihat dari kriteria prestasi yang meningkat pada tahun 2019 dibandingkan tahun 2018. ${ }^{32}$

Sistem rekrutmen dan sistem pelatihan kedua hal tersebut sangat berpengaruh terhadap kinerja karyawan di Bank Syariah SPM Pamekasan. Karena jika kedua sistem tersebut diterapkan dengan baik maka akan berdampak baik pula terhadap kinerja para karyawan. Oleh sebab itu Bank Syariah SPM Pamekasan harus memperhatikan dengan sebaik mungkin akan kedua sistem tersebut karena dalam menjalankan sebuah perusahaan dengan baik maka diperlukan juga karyawan yang baik pula dalam menjalankan setiap kegiatan yang ada dalam Bank Syariah SPM Pamekasan, sehingga nantinya tujuan-tujuan yang ingin dicapai Bank Syariah SPM Pamekasan dapat terpenuhi.

\section{Kesimpulan}

Sistem rekrutmen yang diterapkan di Bank Syariah SPM Pamekasan yaitu dengan menggunakan sistem rekrutmen internal serta eksternal, untuk rekrutmen internal di Bank Syariah SPM Pamekasan diterapkan karena ada kenaikan jabatan bagi karyawan yang sudah lama. Sedangkan untuk rekrutmen eksternal yang ditetapkan oleh Bank Syariah SPM Pamekasan menggunakan media diantaranya yaitu koran, brosur, radio karimata, internet dan dari mulut kemulut. Sistem rekrutmen eksternal disini mengambil dari surat lamaran yang sudah disetorkan ke Bank syariah SPM Pamekasan. Sehingga nantinya pelamar akan dipanggil dan dilakukan beberapa teks yaitu berupa teks tulis dan wawancara.

Adapun untuk sistem pelatihan yang diterapakan oleh Bank Syariah SPM Pamekasan yaitu menerapkan sistem pelatihan internal dan eksternal. Dimana untuk pelatihan internal Bank Syariah SPM Pamekasan akan diberikan sebuah pelatihan kepada karyawan lama ataupun pada karyawan baru, untuk karyawan baru disini akan diberikan pelatihan khusus selama kurang lebih satu minggu. Sedangkan untuk pelatihan eksternal disini Bank Syariah SPM Pamekasan akan mengirim beberapa karyawan sesuai dengan jabatannya untuk dapat mengikuti pelatihan yang diselenggarakan oleh bank-bank lain

Sistem rekrutmen dan pelatihan yang dijalankan oleh Bank Syariah SPM Pamekasan cukup baik dan juga berpengaruh terhadap kinerja para karyawan. Hal tersebut dapat dilihat dari peningkatan kinerja karyawan pada tahun 2019 dibandingkan tahun 2018. Sistem rekrutmen yang dijalankan Bank Syariah SPM berpengaruh pada kriteria kedisiplinan, keaktifan karyawan dalam bekerja hal tersebut nantinya akan meningkatkan kinerja para karyawan sehingga akan berdampak positif bagi Bank Syariah SPM sendiri. Hal tersebut juga dapat dilihat dari kriteria kedisiplinan dan keaktifan para karyawan yang meningkat pada tahun 2019 dibandingkan tahun 2018.

${ }^{32}$ Iqbal, Wawancara, 22-Oktober-2020. 
Sedangkan Untuk sistem pelatihan yang diterapkan di Bank Syariah SPM disini yaitu pelatihan internal dan eksternal. Pelatihan yang dilakukan oleh Bank Syariah SPM Pamekasan juga berdampak pada kinerja karyawan karena pelatihan tersebut dapat menjadi tambahan pengetahuan dan kesemangatan karyawan dalam bekerja dan juga dapat berdampak positif untuk kriteria prestasi karyawan yang mana nantinya untuk kriteria prestasi karyawan dilihat dari kemampuan karyawan dalam mencapai target yang sudah ditetapkan oleh pihak bank. Kriteria prestasi pada tahun 2019 mengalami peningkatan dari pada tahun 2018 di Bank Syariah SPM Pamekasan.

\section{DAFTAR PUSTAKA}

Abdullah, Boedi dan Saebani, Beni Ahmad Metode Penelitian Ekonomi Islam Muamalah, Bandung: CV Pustaka Setia, 2014.

Amalia, Nika Rizki. Proses Rekrutmen dan Seleksi Karyawan Pada BMT Alfa Dinar Kantor Pusat Karanganyar, Skripsi IAIN Salatiga, 2017.

Doni, Wawancara, 30-September-2020

Gita, Wawancara, 14-Oktober-2020.

Herry, E., Permana, P. Y. E., Aji, W. B., \& Muhtadi, R. (2019). Total Quality Management Development and Sharia Governance Efforts in Sharia Micro Financial Institutions to Improve Market Share. IJIEEB International Journal of Integrated Education, Engineering and Business eISSN 2615-1596 pISSN 2615-2312, 2(1), 27-35.

Iqbal, Wawancara, 15-Oktober-2020.

Lubis, M. Z. M. (2020). POLA REKRUTMEN DAN SELEKSI KARYAWAN PADA BMT. FreakonomicS: Journal of Islamic Economics and Finance, 1(1), 23-33..

Mansur, M. (2018). BANK SYARIAH: Antara Labelisasi dan Pemberdayaan Ekonomi Masyarakat. Ulumuna: Jurnal Studi Keislaman, 4(1), 54-70.

Muslikhin, M., Kinanti, R. A., Muhtadi, R., \& Fudholi, M. (2020). PEMERIKSAAN EMPIRIS PADA PENGARUH KINERJA SOSIAL TERHADAP PROFITABILITAS DI BANK SYARIAH. Ulumuna: Jurnal Studi Keislaman, 6(1), 72-84.

Muzakki, M., Eliyana, A., \& Muhtadi, R. (2019). Is employee performance affected by organizational cuoture, work motivation and organizational citizenship behavior (OCB)?: An empirical investigation. IJIEEB International Journal of Integrated Education, Engineering and Business eISSN 2615-1596 pISSN 2615-2312, 2(1), 3642. 
Nurhuda Erwin. "Analisis Pelaksanaan Program Rekrutmen, Seleksi, Penempatan Kerja, dan Pelatihan-Karyawan", Jurnal, Administrasi Bisnis (JAB), Vol. 9, No. 1, April 2014.

Prawesti Intan, Analisis Sistem Rekrutmen, Penempatan, dan Pelatihan Dalam Meningkatkan Kinerja Karyawan BMT Permata Jatim, Skripsi. Surabaya: UIN Sunan Ampel, 2018.

Purwati Wiwin, Implementasi Nilai-Nilai Islam Dalam Proses Rekrutmen dan Pengembangan Karyawan Di BMT Muamalat Limpung, Skripsi. Semarang: UIN Walisongo, 2015.

Rosyadah, P. C., Arifin, N. R., Muhtadi, R., \& Safik, M. (2020). Factors That Affect Savings In Islamic Banking. AL-ARBAH: Journal of Islamic Finance and Banking, 2(1), 33-46

Setyawati, Dwi Wahyu Marina. Analisis Proses Rekrutmen Karyawan Pada KSPS BMT Surya Melati Gubug Grobogan, Skripsi. IAIN Salatiga, 2019.

Suhari, Wawancara, 30-September-2020.

Sunarsi, Denok. "Pengaruh Rekrutmen, Seleksi dan Pelatihan Terhadap Produktivitas Kerja Karyawan”, Jurnal KREATIF: Pemasaran, Sumber Daya Manusia dan Keuangan, Vol. 6, No. 1, Januari 2018.

Sutrisno, Edy, Manajemen Sumber Daya Manusia, Jakarta: Kencana Prenadamedia Group, 2009. 